UDC 347.2

DOI https:/ / doi.org/10.32841/ILA.2020.24.03

\author{
GUYVAN P. D., \\ Ph. D. in Jurisprudence, Honored Lawyer of Ukraine, \\ Professor \\ Poltava Institute of Business
}

\title{
THE CONCEPT OF A REASONABLE PERIOD OF PROCEEDING IN INTERNATIONAL AND UKRAINIAN LAW ENFORCEMENT
}

Summary. The scientific article is devoted to the study of the topical issue of temporal certainty in the implementation of justice in the Ukrainian legal system. It is emphasized that the model in the organization of the national judiciary, in particular, regarding its observance of temporal rules of efficiency, is international practice, first of all - the decision of the European Court of Human Rights. This paper proposes a scientific assessment of objective and subjective factors that affect the timeliness of proceedings. The elements that ensure the temporal stability of a person's right to judicial protection are analyzed. Some components of the concept of "reasonable time" of the process, including its interpretation by the European Court of Human Rights, have been studied. It is established that a "reasonable time" cannot be clearly established for all types of disputes, but to assess whether the time in these circumstances met the parameters of reasonableness, should be based on established in judicial practice factors as basic criteria for this phenomenon. For civil disputes, such criteria include the complexity of the case from both the factual and legal side, the plaintiff's conduct, the timeliness of the actions of the judiciary, public authorities, the importance of the case for the person concerned. It is emphasized that a subjective factor, such as the legality of the decision, is also significant. After all, the issuance of an unfounded and unmotivated verdict leads to the issuance of illegal, in terms of substantive law, court decisions. In the temporal sense, such a violation of the law leads to a delay in the consideration of the case, non-compliance with a reasonable time due to the need to review and cancel the unfair decision on appeal or cassation. Examples of ambiguity and inconsistency of the current procedural legislation are given, which contributes to unjustified delays in the consideration of cases and even illegal refusal of access to court. Relevant proposals have been made to amend the legislation.

Key words: temporal certainty, reasonable term, timeliness of court proceedings.

Formulation of the problem. Legal certainty as an integral element of the rule of law, enshrined in the Convention for the Protection of Human Rights and Fundamental Freedoms, is inherent in the legal system in the field of both lawmaking and law enforcement, including at the stage of judicial proceedings. At the same time, great importance is attached to the certainty of temporal characteristics in the creation of acts of law and their use to regulate social relations and protect the subjective rights of the individual. An important role is played 
by indicators of the quality of the rule of law in the temporal dimension, which guarantees the principle of legitimate expectations of the person, his confidence in the stability of legal acts and actions, their irreversibility and consistency, the rules to the persons etc.

In addition to guaranteeing the temporal stability and fairness of the rule of law (this shows the importance of the principle of legal certainty in the field of lawmaking), legal certainty must be achieved in the field of law enforcement. In this context, the studied principle is widely used in the decisions of the European Court of Human Rights. At the same time, it covers several separate manifestations, which have different directions, but, nevertheless, all of them are aimed at achieving a common result - ensuring certainty of law enforcement and thus effective protection of individual rights. Therefore, in resolving a specific case, the European Court achieves the implementation of the theoretical requirement to adjust a certain rule, eliminate its ambiguity, provide clarity and clarity of its content.

Analysis of recent research and publications. In scientific journalism, the work of such scientists as M. Buromensky, D. Gomien, O. Goncharenko, V. Gorodovenko, V. Marmazov, O. Prokopenko, P. Rabinovych, D. Suprun, S. Shevchuk and others. However, these studies were aimed at providing a general description of the concept of fair trial, including in its temporal dimension. At the same time, doctrinal developments of concepts on the effectiveness of timely enforcement by European institutions and its adaptation to the Ukrainian legal mechanism are still extremely insufficient. The issue of legal consequences for a country if it is found to have committed violations of the Convention remains virtually unexplored, as evidenced by the practice of repeated appeals to the ECtHR for violations for which the body has already been prosecuted.

The purpose of this article is to analyze the legal results of ECtHR judgments against Ukraine in the context of the implementation of specific organizational measures of the state to bring its legislation and law enforcement practice to European standards to ensure timely and fair consideration of cases.

Presenting main material. The European Court of Justice uses the notion of "reasonable time" (Article $6 \$ 1$ of the Convention for the Protection of Human Rights and Fundamental Freedoms) to determine the appropriate length of proceedings. At the same time, the shortest term of consideration and resolution of a court case, sufficient to provide timely (without unjustified delays) judicial protection of violated rights, freedoms and interests of a person, is interpreted as reasonable. In the national Ukrainian procedural legislation one can also notice the attempts of normative solution of this issue. Thus, in Part 2 of Art. 210 of the Code of Civil Procedure (CPC) states that the court considers the case on the merits within thirty days from the date of the hearing on the merits. Special terms of consideration are set for some cases of separate proceedings, such as an application for compulsory psychiatric care (considered by the court within the following terms from the date of its receipt in court: on hospitalization of a person in a psychiatric institution - within 24 hours; on psychiatric examination - within 
three on the provision of outpatient psychiatric care, its continuation and extension of hospitalization - within ten days (Article 349 of the CPC), the disclosure by the bank of information containing banking secrecy (five days from the date of receipt of the application (Article 289 of the CPC), compulsory hospitalization in an anti-tuberculosis institution or on the continuation of treatment (no later than 24 hours after the opening of proceedings) (Article 345 of the CPC).

However, this definition does not completely coincide with the European interpretation of the essence and content of the "reasonable period". After all, according to the principles followed by the ECtHR, the concept of consideration of the case within a reasonable time is evaluative. It means the time required for the correct and fair resolution of each case in the procedural form prescribed by law. Therefore, a "reasonable time" cannot be clearly established for all types of disputes, but to assess whether the time in these circumstances met the parameters of reasonableness, should be based on factors established in case law as the basic criteria for this phenomenon. For civil disputes, such criteria include the complexity of the case both in fact and in law, the behavior of the plaintiff, the judiciary, public authorities, the importance of the case for the person concerned $[1$, p. 15-17]. A significant circumstance is a subjective factor, such as the legality of the decision. After all, the issuance of an unfounded and unmotivated verdict leads to the issuance of illegal, in terms of substantive law, court decisions.

In the temporal sense, such a violation of the law leads to a delay in the consideration of the case, non-compliance with a reasonable time due to the need to review and cancel the unfair decision on appeal or cassation. Finally, incorrect justification due to the substitution of concepts, distortion and disregard by national courts of the plaintiff's position and appealing such actions to the European Court significantly delays the moment of reaching the truth from the actual time of the offense. For example, in the case of Shapovalov v. Ukraine, the ECtHR found that the applicant had tried in 2004 to obtain information on the conduct and results of the presidential election in Ukraine, but had been refused by the Territorial Election Commission. All national courts also denied the applicant protection of his right to information, stating that he was challenging the election procedure. Disagreeing with this position, the ECtHR noted that in this case the applicant was a journalist and requested information for his professional activities, ie for publication in connection with the elections. Failure to do so could damage his business reputation and career. Therefore, the European Court, recognizing the fact of violation of paragraph 1 of Art. 6 of the Convention, concluded that the domestic courts had misunderstood the applicant's complaint, namely that it had raised not the issue of the 2004 presidential election procedure but the issue of access to information $[2, \$ \$ 49,55,57]$.

Such examples of intentional or unintentional distortion of the position of a person who appeals to administrative or judicial bodies in order to obtain proper and fair application of legal norms are quite indicative of the domestic legal system. For example, a popular violation of a person's right to information is the recognition of his information request not by an appropriate action aimed 
at obtaining it, but by a citizen's request. Freedom to seek, receive and impart information is one of the most important political and personal human rights and is included in the Universal Declaration of Human Rights (Article 19). Article 34 of the Basic Law of Ukraine states that everyone has the right to freely collect, store, use and disseminate information orally, in writing or otherwise - at their discretion. Article 32 of the Constitution also states that every citizen has the right to acquaint himself with information about himself in state authorities, local self-government bodies, institutions and organizations that is not a state or other secret protected by law.

Special laws in Ukraine regulate the procedure for access to information, including by submitting an information request. The Law of Ukraine "On Access to Public Information" defines the procedure for exercising and ensuring the right of everyone to access information held by subjects of power, other managers of public information defined by this Law, and information of public interest. information means information reflected and documented by any means and on any media, which was received or created in the course of performance by subjects of power of the duties provided by the current legislation, or which is in possession of subjects of power powers, other managers of public information, defined by this Law.

By qualifying the information request sent to the information manager as a citizen's request, the latter thus makes a substitution of concepts in order to use inappropriate means of response. Differences in these ways of communication between a citizen and the authorities are given in the explanation of the Ministry of Justice of Ukraine dated May 3, 2012. In particular, it states that the right of appeal and the right of access to public information are closely linked. However, it is necessary to distinguish between a citizen's appeal and a request for information. The right to appeal is a proposal (remarks), statement (petition) and complaint (Article 3 of the Law of Ukraine "On Citizens' Appeals") set forth in writing or orally, to subjects of power, associations of citizens, enterprises, institutions, organizations regardless of ownership, media. Instead, a request for information means a request of a person to the information manager to provide public information in his possession (Article 19 of the Law of Ukraine "On Access to Public Information"). The appeal concerns the defense of the rights and legitimate interests of the citizen and proposals for the activities of the subjects of power, exposing their shortcomings (comments) in the work. And requests for information are about providing public information, which is owned or should be owned by its administrator. Therefore, the timing and procedure for responding (and thus the ways in which the rights of the person who applied to the subject of authority were violated) differ significantly. For example, a response to a request for information must be sent within 5 days, and a request must be sent within 30 days of receipt by the relevant authority. Establishing the real essence of the relationship is crucial for the judicial protection of specific rights of the individual. Otherwise, the decision of the law enforcement body will inevitably acquire signs of improper validity and unmotivated, therefore - can not claim legitimacy. 
We should also note that the duration of the process is inevitably influenced by the certainty of the current legislation. Its inconsistency, ambiguity, which causes different interpretations and applications, can seriously and unjustifiably delay the process. This is often manifested in differences in procedural laws regarding the jurisdiction of certain disputes. For example, there are recurring situations where, for example, an entity is suing a commercial court and the case is pending in a court of general jurisdiction. In this case, the judge refuses to accept the statement of claim, because the application is not subject to consideration in the commercial courts of Ukraine (Part 1 of Article 175 of the Code of Civil Procedure). The basis for the return of the statement of claim, appeal or cassation appeal, which affects the duration of the process, in this case is the need for the applicant to comply with certain procedural requirements established by law: send the application to a particular court, pay court fees, provide copies of documents. If these obligations of the applicant are established by law, then, as a rule, their non-observance makes it impossible to consider the dispute. However, such a rule is not always applied by the ECtHR. In considering the case of Kreuz v. Poland $[3, \S 53]$, the Court noted that the right to a court was not absolute. It may be subject to restrictions permitted by the content, because the right of access to a court by its very nature requires regulation by the state. However, a restriction will not be compatible with Article $6 \$ 1$ of the Convention if it has no legitimate aim and if there is no proportional relationship between the means employed and the aim pursued. The same applies to cases of misapplication of the rule of legal certainty to establish the jurisdiction of certain courts, which leads to a violation of the human right to a timely hearing of his case, and even in general - to access to court.

For example, when considering a case on a person's claim to declare illegal the decision of the Kyiv District Council in Poltava city to issue a permit for a land use plan for a plot of land owned by the plaintiff, has a cadastral number, but not reflected in the city master plan, and the administrative court and court general jurisdiction alternately refused to consider the case due to its incompetence in these courts. This was largely due to the inconsistency of the decisions of the plenums of the relevant courts, which differently determined the substantive jurisdiction of the cases, and as a result suffered specific entities in need of protection. As a result of such ping-pong, the established six-month term for appealing to administrative courts expired, and if it had not been for the intervention of the appellate instances, the plaintiff would have been deprived of the right of access to court at all [4].

To address this issue, a precedent-setting law enforcement approach has been developed, which illustrates the interpretation used by the European Court in several cases. For example, in the case of Peretyaka and Sheremetyev $\mathrm{v}$. Ukraine, it was established that the dispute over the payment of pensions to former pensioners, which was considered by national courts of first and appellate instances in civil proceedings, due to changes in procedural law - entry into force The Code of Administrative Procedure from September 1, 2005 - came under 
the jurisdiction of administrative justice. Therefore, the cassation appeals filed in accordance with the legislation in force at the time of review of decisions on appeal to the Supreme Court of Ukraine within two months were forwarded by the latter to the Supreme Administrative Court of Ukraine, which refused to consider because the one-month period provided by CASU for cassation appeal, was omitted. The European Court has ruled that under such conditions, the restriction of the right of access was applied disproportionately $[5, \$ \$ 36,40]$.

In other cases, due to the competition of the relevant codes, cassation appeals against court decisions on pension disputes submitted to the Supreme Court (SCU) and subsequently submitted by it to the High Administrative Court (HAC) were rejected by the latter as those to be considered in civil proceedings. Noting the violation of Art. 6 of the Convention, the European Court reasoned that the HAC did not act in accordance with the instructions of the SCU, which according to the Constitution is the highest instance in the system of courts of general jurisdiction. The jurisdiction of the Supreme Court should extend to the settlement of disputes between higher specialized courts, in particular in matters of procedural law. The Supreme Court must decide on the admissibility of cases in which the law is inconsistent. It must also resolve disputes over jurisdiction between three jurisdictions (civil and criminal, commercial, administrative) [6, para. 25]. The refusal of the HAC to consider the applicants' cassation appeals contrary to the decisions of the SCU not only deprived the applicants of access to court, but also undermined the authority of the judiciary.

Thus, as we can see, this situation was associated not only with some difficulty in establishing jurisdiction in certain categories of cases, but also with the lack of certainty of the act itself (Code of Administrftive Jurisdiction), which was adopted by Parliament, in terms of failure to ensure the principle of guaranteeing legitimate expectations. personality and proportionality in the application of the new act by introducing a transitional period. This led, in particular, to the fact that some cassation appeals remained simply unresolved. The problem of inconsistency between the courts' positions on jurisdiction, which ultimately led to a violation of a person's right to a fair trial, led to a finding of non-compliance with Article 6 of the Convention in the Church of Sosulivka v. Ukraine. In particular, the applicant organization's claim for the transfer of the church premises for exclusive use was not considered in either civil or commercial proceedings, as the courts of each jurisdiction referred to the jurisdiction of a court of another jurisdiction. In considering this case, the Court reiterated that its task was not to examine whether, in particular in the light of Article 17 of the Law of Ukraine "On Freedom of Conscience and Religious Organizations", courts of general jurisdiction or commercial courts had jurisdiction to consider the merits or which of these courts is competent to consider the applicant's complaints on the merits. The court noted that the applicant had had access to these courts, but none of them had considered the merits of his complaint about the inability to use the church building, as they considered that they had no jurisdiction to deal with such matters, despite procedural admissibility requirements. The Court 
therefore concludes that this situation is tantamount to a denial of justice, which violates the very essence of the applicant's right of access to a court, which is guaranteed by Article $6 ₫ 1$ of the Convention. Accordingly, there was a violation of this provision [7, paragraphs 51,53].

A similar situation was also considered by the ECtHR in the case of Sutyazhnik v. Russia. The applicant complained about the illegality of the rules of the Arbitration Procedure Code, which presuppose ambiguity in the interpretation of the jurisdiction of the arbitration law over non-profit organizations. In fact, the reason for the annulment of the lower courts' decisions under supervision was that the dispute between the applicant and his opponent was outside the jurisdiction of the arbitral tribunals. The issue of errors of jurisdiction, in principle, can be considered a "significant shortcoming" that can be remedied by supervision. However, the question arises as to whether, in certain circumstances of the case, a breach of the rules of jurisdiction may be regarded as a ground for reviewing a decision which the applicant considers res judicata. Having clarified the specific circumstances of this case, the European Court concluded that it did not see any urgent public need that would justify a departure from the principle of legal certainty. The decision of the arbitral tribunal was overturned, primarily in the interests of legal purism, and not in order to correct an error that is significant for the judicial system [8, paragraphs 37-38].

In Ukrainian law enforcement practice, cases of inconsistency of interpretations of certain provisions of the same law by different national courts are also indicative. For example, in Matsyuk v. Ukraine [9] the Court found a violation of Article $6 \$ 1$ of the Convention on the ground that the applicant had been deprived of the practical opportunity to challenge the refusal to pay compensation under Article 12 of the Law of Ukraine "On Compensation actions of bodies of inquiry, pre-trial investigation, prosecutor's office and court "as a result of improper registration by law enforcement agencies of the corresponding document. The fact was that the tax police had instituted and then closed several criminal cases against the applicant in connection with the misappropriation of property and tax evasion. The applicant subsequently twice applied to the tax police for compensation for non-pecuniary and pecuniary damage caused to him as a result of the criminal proceedings, but the tax police refused to comply with these claims, as stated in a letter. Having received the refusal drawn up in this way, the applicant applied for compensation to the court, which in turn refused to hear his complaint because the refusal of the tax police was set out in the form of a letter and not a ruling. The applicant re-applied to the tax police, but the result was the same: the latter systematically refused to satisfy the extrajudicial claims by letter, while the judicial authorities did not recognize the document as an object of appeal. The courts of three instances therefore dismissed the applicant's claim for non-pecuniary damage, which the European Court had found to be a violation of his right of access to a court.

From the above we can draw certain conclusions. As we can see, the non-absolute right of access to court, in circumstances when the state itself is not able to properly resolve conflicts and differences on procedural issues related to 
the jurisdiction of individual cases, leads to unjustified denial of access to court, undue delay, and thus to arbitrariness and violation of the right to a fair trial. The Venice Commission tried to resolve the problem of contradictions between national courts of different jurisdictions. Thus, in its conclusion at the 84th plenary session, this body pointed out that the creation of three different jurisdictions in Ukraine, headed by three courts of cassation, independent of each other, could lead to numerous and often complex conflicts of jurisdiction. At the very least, what can be expected in such a situation: the creation of an effective system, such as a special court of "conflicts" to resolve such conflicts. The Supreme Court could be suitable for this purpose, but its jurisdiction as a court of cassation is limited to the application of substantive law. It is not clear why the Supreme Court should be denied jurisdiction over procedural law, especially if most issues of a fair trial (Article 6 of the European Convention on Human Rights) concern procedural issues. Differences in the jurisprudence of higher specialized courts may also arise in connection with the rules of procedural law, and therefore it would be useful if there was an instance capable of ensuring equal application in these matters. The Supreme Court must provide a general interpretation of the law of the highest judicial body and, thus, ensure the same interpretation of the law by all courts even before conflicts arise [10, paragraphs 28-29, 31].

At present, the issues raised in this paper could be resolved by regulating their regulation in the new versions of the legislation on the judiciary and procedural codes. Unfortunately, we must state the vagueness of the wording in these laws (for example, paragraph 6), Part 2 of Art. 36 of the Law "On the Judiciary and the Status of Judges"). Therefore, it is hoped that the Ukrainian judiciary will apply the practice of European law enforcement more widely, and thus ensure respect for human rights to a fair trial.

\section{References:}

1. Guyvan P.D. The importance of temporal factors in the case law of the European Court of Human Rights. Part 2. Criteria of reasonableness of the term of the process under the European Convention and Ukrainian law enforcement realities. Підприємництво, господарство і право. 2017. № 7. Р. 14-19.

2. Judgment of the European Court of Human Rights of 31 July 2012 in the case of Shapovalov v. Ukraine, application № 45835/05, URL: https://precedent.in.ua/2016/05 / 15 / shapovalov-protyv-ukrayny-2 /

3. Judgment of the European Court of Human Rights of 19 June 2001 in the case of KREUZ v. POLAND, application no. 28249/95, URL: http://zakon2.rada.gov.ua/ laws / show / 980_030

4. Decision in the case № 552/7393/17. Archive of the Kyiv District Court of Poltava for 2017.

5. Judgment of the ECtHR of 21 December 2010, final of 20 June 2011 in Peretyaka and Sheremetyev v. Ukraine, applications № 17160/06 and 35548/06, URL: http://zakon3.rada.gov.ua/laws/show/974_657

6. Judgment of the ECtHR of 9 December 2010, final of 9 March 2011 in Bulanov and Kupchik v. Ukraine, applications № 7714/06 and 23654/08, URL: http://zakon5.rada.gov.ua/laws/show/974_664 
7. Judgment of the European Court of Human Rights of 28 February 2008 in the case "Church of the village of Sosulivka v. Ukraine", application No. 37878/02, URL: http://zakon2.rada.gov.ua/laws/show/974_350

8. Judgment of the European Court of Human Rights of 23 July 2009 in the case of Sutyazhnik v. The Russian Federation, application № 8269/02. URL: http://hrlibrary.umn.edu/russian/euro/Rsutyajnikcase2009.html

9. Judgment of the ECtHR of 10 December 2009, final of 10 March 2010 in Matsyuk v. Ukraine, application № 1751/03, URL: http://taxlink.ua/ua/court/sprava-macyuk-proti-ukraini/

10. Joint Opinion № 588/2010 of the European Commission "For Democracy through Law" (Venice Commission) on the Law of Ukraine "On the Judiciary and the Status of Judges”. URL: http://search.ligazakon.ua/1_doc2.nsf/link1/MU10109.html

Гуйван П. Д. Концепція розумного строку судочинства в міжнародному та українському правозастосуванні

Анотація. Стаття присвячена дослідженню актуального питання часової визначеності під час здійснення судочинства в українській правовій системі. Наголошується, що взірцем в організації національного судівництва, зокрема, щодо дотримання ним темпоральних правил ефективності, $є$ міжнародна практика, насамперед - рішення Європейського суду з прав людини. В цій роботі пропонується наукова оцінка об'єктивних та суб'єктивних факторів, які впливають на своєчасність судочинства. Проаналізовано елементи, що забезпечують темпоральну стабільність права особи на судовий захист. Досліджено окремі складники поняття «розумний строк» процесу, у тому числі його тлумачення Європейським судом із прав людини. Встановлено, що «розумний строк» не може бути чітко встановлений для усіх видів спорів, але для оцінки того, чи відповідав строк у цих обставинах параметрам розумності, слід опиратися на встановлені у судовій практиці чинники як базові критерії дцього явища. Для цивільно-правовох спорів до подібних критеріїв необхідно віднести складність справи як із фактичного, так і правового боку, поведінку позивача, своєчасність дій судової установи, органів державної влади, важливість справи для зацікавленої особи. Підкреслюється, що істотним $є$ і субєктивний чинник, такий як законність рішення. Адже постановлення необгрунтованого та немотивованого вердикту приводить до винесення неправомірних, з погляду норм матеріального права, судових рішень. У темпоральному сенсі таке порушення закону призводить до затягування розгляду справи, недотримання розумного строку процесу внаслідок необхідності перегляду та відміни несправедливого рішення в апеляційному чи касаційному порядку. Наведені приклади неоднозначності та суперечливості чинного процесуального законодавства, що сприяє невиправданому затягуванню розгляду справ та навіть неправомірній відмові у доступі до суду. Надані відповідні пропозиції щодо коригування законодавства у цій сфері.

Ключові слова: часова визначеність, розумний строк, своєчасність судочинства. 